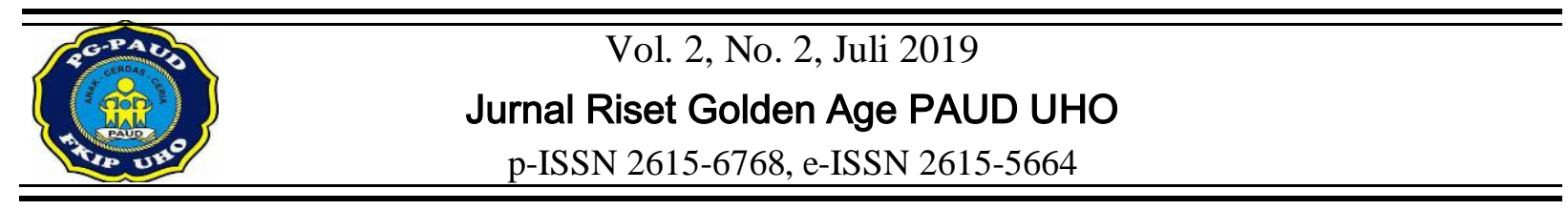

\title{
MENINGKATKAN KREATIVITAS DALAM MEMBENTUK OBJEK MELALUI KARDUS
} GEOMETRI

\author{
Fita Sari ${ }^{1)}$, Nurhayati ${ }^{1)}$, Salim ${ }^{2)}$ \\ ${ }^{1}$ Jurusan PG-PAUD, Universitas Halu Oleo. Jln. H.E.A Mokodompit, Kendari 93232, Indonesia. \\ ${ }^{2} J u r u s a n$ Pendidikan Matematika, Universitas Halu Oleo. Jln. H.E.A Mokodompit, Kendari 93232, \\ Indonesia.
}

\begin{abstract}
Abstrak
Penelitian ini bertujuan untuk meningkatkan kreativitas anak dalam membentuk objek melalui kardus geometri di Kelompok B TK Kondowa Kecamatan Pasarwajo Kabupaten Buton. Jenis penelitian ini adalah Penelitian Tindakan Kelas yang dilakukan dalam dua siklus. Penelitian ini dilaksanakan dalam dua siklus. Tahapan dalam penelitian ini mengikuti prosedur penelitian tindakan kelas, yaitu: (1) Perencanaan, (2) Pelaksaan Tindakan, (3) Observasi dan evaluasi, dan (4) Refleksi. Subjek dalam penelitian ini adalah guru dan anak didik Kelompok B TK Kondowa Kecamatan Pasarwajo Kabupaten Buton yang berjumlah 15 orang anak didik yang terdiri atas 7 orang anak lakilaki dan 8 orang anak perempuan dengan rentang 5-6 tahun.Temuan penelitian terhadap hasil belajar anak didik tentang peningkatan kreativitas dalam membentuk objek melalui kardus geometri diperoleh persentase ketercapaian pada siklus I sebesar $66,7 \%$ dan pada siklus II meningkat menjadi $93,3 \%$. Sedangkanpada aktivitas belajar anak didik siklus I dari $57,1 \%$ pada siklus II mengalami peningkatan menjadi 92,8\%.Dengan demikian dapat disimpulkan bahwa kreativitas dalam membentuk objek di kelompok B TK Kondowa Kecamatan Pasarwajo Kabupaten Buton dapat ditingkatkan melalui kardus geometri.
\end{abstract}

Kata kunci: Kreativitas, Membentuk Objek, Kardus Geometri

\section{IMPROVE CHILDREN'S CREATIVITY IN FORMING OBJECTS THROUGH GEOMETRIC CARDBOARD}

\begin{abstract}
Abstrack
This study aims to improve children's creativity in forming objects through geometric cardboard in Group B Kondowa Kindergarten Pasarwajo District, Buton Regency. This type of research is Class Action Research conducted in two cycles. This research was conducted in two cycles. The stages in this study follow the procedure of classroom action research, namely: (1) Planning, (2) Implementation of Actions, (3) Observation and evaluation, and (4) Reflection. The subjects in this study were teachers and students of Group B Kondowa Kindergarten Pasarwajo District Buton Regency which consisted of 15 students consisting of 7 boys and 8 girls with a range of 5-6 years. Research findings on children's learning outcomes students about increasing creativity in forming objects through geometric cardboard obtained the percentage of achievement in the first cycle of $66.7 \%$ and in the second cycle increased to 93.3\%. While the learning activities of students in cycle I from $57.1 \%$ in the second cycle experienced an increase to $92.8 \%$. Thus it can be concluded that creativity in forming objects in group B of Kondowa TK Pasarwajo District of Buton Regency can be improved through cardboard geometry.
\end{abstract}

Keywords: Creativity, Forming Objects, Cardboard Geometry

\section{PENDAHULUAN}

Undang-Undang Nomor 20 tahun 2003 tentang sistem pendidikan nasional Bab 1 Pasal 1 Ayat 14 menyatakan bahwa Pendidikan Anak Usia Dini adalah suatu upaya pembinaan yang ditujukan kepada anak sejak lahir sampai dengan usia enam tahun yang dilakukan melalui pemberian rangsangan pendidikan untuk membantu pertumbuhan dan perkembangan jasmani dan rohani agar anak memiliki kesiapan dalam pendidikan lebih lanjut. Lebih lanjut 
dalam Undang-Undang No. 20 tahun 2003 tentang Sistem Pendidikan Nasional, disebutkan bahwa pendidikan adalah usaha sadar dan terencana untuk mewujudkan suasana belajar dan proses pembelajaran agar peserta didik secara aktif mengembangkan potensi dirinya untuk memiliki kekuatan spiritual keagamaan, pengendalian diri, kepribadian, kecerdasan, akhlak mulia, serta keterampilan yang diperlukan dirinya, masyarakat, bangsa, dan negara (Fadlillah, 2012: 65).

Salah satu aspek yang dapat mengasah kecerdasan anak yaitu dengan adanya kreativitas. Semiawan (Rachmawati dan Kurniati, 2010: 14) mengemukakan bahwa kreativitas merupakan kemampuan untuk memberikan gagasan baru dan menerapkannya dalam pemecahan masalah.

Kamus Besar Bahasa Indonesia, kreativitas berasal dari kata "kreatif" yang berarti memiliki daya cipta, memiliki kemampuan untuk menciptakan, bersifat (mengandung) daya cipta, pekerjaan yang menghendaki kecerdasan dan imajinasi. "Kreativitas" adalah kemampuan untuk mencipta, daya cipta, perihal berkreasi, kekreatifan, yang secara hakiki merupakan hasil kerja keras.

Kreativitas adalah bentuk aktivitas imajinatif yang mampu menghasilkan sesuatu yang bersifat orisinal, murni, asli dan bermakna (Anna, 2004:17). Kreativitas merupakan bakat yang secara potensial dimiliki setiap orang, dapat diidentifikasi dan dipupuk melalui pendidikan yang tepat, di antaranya pada Taman Kanak-kanak sebagai salah satu tempat diselenggarakannya Pendidikan Anak Usia Dini. Kreativitas salah satu potensi yang dimiliki setiap individu, penting untuk dikembangkan sejak usia dini (Rachmawati \& Kurniati, 2005: 8). Karena pada masa ini individu memiliki peluang yang sangat besar untuk dapat mengembangkan potensi tersebut.

Ayan dalam Rachmawati dan Kurniati (2010: 16) melengkapi ciri kepribadian orang kreatif dengan menambahkan beberapa karakteristik, sebagai berikut : a) antusias; b) berpikiran terbuka; c) bersikap spontan; d) cakap; e) giat dan rajin: f) gigih; g) ingin tahu; h) kritis; i) mampu menyesuaikan diri; j) mandiri; k) percaya diri; l) toleran terhadap resiko; $\mathrm{m}$ ) bersemangat; $\mathrm{n}$ ) orisinal atau unik; o) mudah bergerak; $p$ ) penuh daya cipta; q) penuh pengertian; r) selalu sibuk; s) pengamat; t) sulit ditebak; u) tekun.
Kreativitas merupakan hal yang penting dalam masa pertumbuhan anak usia dini. Dengan kreativitas anak akan memperoleh kesempatan sepenuhnya untuk memenuhi kebutuhan berekspresi menurut caranya sendiri yang dituangkan dalam bentuk hasil karya anak. Berkreasi dengan kardus geometri merupakan kegiatan yang menarik dan menyenangkan bagi anak, terlebih jika media yang digunakan bervariasi.

Utami (1992: 34) mengemukakan bahwa pengembangan kreativitas bagi anak memiliki tujuan: 1) mengenalkan cara mengekspresikan diri melalui hasil karya dengan menggunakan teknik-teknik yang dikuasainya; 2) mengenalkan cara menemukan alternatif pemecahan masalah; 3) membuat anak memiliki sikap keterbukaan terhadap berbagai pengalaman dengan tingkat kelenturan dan toleransi yang tinggi terhadap ketidakpastian; 4) membuat anak memiliki kepuasan diri terhadap apa yang dilakukan; dan 5) sikap menghargai kasil karya orang lain.

Dari beberapa pendapat para ahli diatas dapat disimpulkan bahwa kreativitas merupakan kemampuan untuk menciptakan sesuatu yang baru untuk memberi ide kreatif dalam memecahkan masalah atau sebagai kemampuan untuk melihat hubungan-hubungan yang baru antara unsur-unsur yang sudah ada sebelumnya.

Berdasarkan hasil observasi yang dilakukan di kelompok B TK Kondowa Kecamatan Pasarwajo Kabupaten Buton, dalam meningkatkan kreativitas dalam membentuk objek melalui kardus geometri di TK Kondowa belum pernah dilakukan sehingga anak masih banyak yang belum dapat mengembangkan kreativitasnya. Kegiatan membuat suatu karya masih dihadapkan berbagai kendala. Hal ini disebabkan beberapa faktor yang menghambat kreativitas, salah satunya yaitu kurangnya latihan dalam membuat hasil karya, sehingga anak tidak dapat mengapresiasi karyanya dengan baik. Selain itu, respon anak selama proses pembelajaran pada kegiatan membuat hasil karya dinilai masih kurang, karena sebagian anak masih dihadapkan pada kegiatan menulis dan menggambar, serta mewarnai pada proses pembelajaran. Oleh karena itu salah satu kegiatan pembelajaran melalui media bentuk geometri dalam mengembangkan kreativitas anak, sangatlah sesuai. Untuk itu agar kreativitas anak di kelompok B TK Kondowa Kecamatan Pasarwajo Kabupaten Buton dapat berkembang secara optimal, penulis tertarik untuk melakukan 
penelitian dengan memanfaatkan bermacam bentuk geometri.

Kardus merupakan bahan kemasan yang digunakan untuk melindungi suatu prodak selama distribusi dari produsen ke konsumen. kardus tersebut terbuat dari bahan dasar berupa kertas yang diketahui mudah sekali mengalami kerusakan.

Geometri adalah bagian dari matematika yang membahas mengenai titik, garis, bidang, dan ruang. Ruang adalah himpunan titik-titik yang dapat membentuk bangun-bangun geometri. Garis adalah himpunan bagian dari ruang yang merupakan himpunan titik-titik yang mempunyai sifat khusus. Bidang adalah himpunan-himpunan titik-titik yang terletak pada permukaan datar (Negoro, 2003: 18).

Tombokan (1996: 29) mengemukakan bahwa geometri merupakan studi tentang ruang dan berbagai bantuk dalam ruang. Pengetahuan tentang geometri sangat berguna dalam kehidupan anak. Anak-anak biasanya senang belajar geometri. Anak mengembangkan konsep-konsep geometri dengan mengamati bantuk-bentuk geometri yang terdapat di sekitar mereka. Sebelum masuk sekolah anak-anak telah mempunyai banyak pengalaman geometri. Anak bermain dengan bangunbangun geometri datar dan ruang dari pengalamannya melalui observasi. Geometri adalah bagian dari matematika yang membahas mengenai titik, garis, bidang, dan ruang.

Dari paparan di atas dapat dianalisis bahwa geometri merupakan studi mengenai bangun ruang dan bangun datar yang digunakan anak untuk mendiskripsikan segala sesuatu yang ada di sekitar anak seperti kardus yang dibentuk menjadi bentuk-bentuk geometri.

\section{METODE}

Jenis penelitian yang digunakan pada penelitian adalah Penelitian Tindakan Kelas (PTK). Suharsimi, dkk (2014:3) penelitian tindakan kelas merupakan suatu pencermatan terhadap kegiatan belajar berupa sebuah tindakan, yang sengaja dimunculkan dan terjadi dalam sebuah kelas secara bersama.

Penelitian ini dilaksanakan di Kelompok B TK Kondowa Kecamatan Pasarwajo Kabupaten Buton. Penelitian ini dilaksanakan pada semester genap tahun pelajaran 2017/2018.

Subjek penelitian tindakan ini adalah anak didik pada kelompok B TK Kondowa yang berjumlah 15 orang yang terdiri atas 7 anak laki- laki dan 8 anak perempuan dengan retang usia 5-6 tahun.

Faktor yang diteliti dan diamati dalam penelitian tindakan kelas ini adalah sebagai berikut: 1) Faktor anak didik, mengamati aktivitas anak dalam mengikuti proses pembelajaran, 2) Faktor guru, mengamati aktivitas guru, 3) Hasil belajar anak

Teknik pengumpulan data yang dilakukan pada penelitian ini dengan menggunakan cara pengamatan/observasi, wawancara, dan dokumentasi. 1) Pengamatan/observasi adalah suatu teknik yang dapat dilakukan guru untuk mendapatkan berbagai informasi atau data tentang perkembangan dan permasalahan anak. Melalui pengamatan, guru dapat mengetahui bagaimana perubahan yang terjadi pada anak dalam satu waktu tertentu, 2). Wawancara dilakukan dengan berkomunikasi kepada guru dan kepala sekolah. 3) Dokumentasi yang digunakan dalam penelitian ini adalah mengambil data anak berupa hasil karya anak pada saat melakukan proses pembelajaran di sekolah dan foto-foto dalam proses pembelajaran berlangsung sebagai data yang mendukung untuk dianalisis.

Teknik analisis data yang digunakan dalam penelitian ini disesuaikan dengan teknik penilaian di Taman Kanak-kanak yaitu dengan menggunakan tanda sebagai berikut: $*=$ Belum Berkembang $(\mathrm{BB}),{ }^{* *}=$ Mulai Berkembang $(\mathrm{MB}), \quad * * *=$ Berkembang Sesuai Harapan $(\mathrm{BSH}), * * * *=$ Berkembang Sangat Baik (BSB) (Depdiknas, 2004: 26).

Indikator keberhasilan untuk mengetahui keberhasilan dalam penelitian tindakan kelas ini dipergunakan kriteria Berkembang Sesuai Harapan (BSH) dan Berkembang Sangat Baik (BSB) minimal $85 \%$ baik secara individual maupun klasikal. Penilaian terhadap kreativitas melalui kardus geometri yang dapat diperhatikan dalambentuk geometri yang di contohkan guru,dievaluasi dengan mengacu pada pedoman pemberian penilaian dalam satuan pendidikan TK. Sedangkan dari segi proses tindakan dikatakan berhasil apabila hasil observasi terhadap guru dan anak telah mencapai minimal $85 \%$ sesuai dengan skenario kegiatan pembelajaran. Indikator kinerja yang diberlakukan bagi guru adalah dimana guru mampu melaksanakan kegiatan penelitian sesuai dengan tahapan siklus penelitian serta guru membimbing, mengarahkan, mengamati dan melaksanakan penilaian pada anak didik. Sedangkan indikator kinerja bagi kegiatan 
pembelajaran adalah pelaksanaaan kegiatan pembelajaran antara guru dan anak didik dapat melaksanakan kegiatan dari awal hingga akhir.

\section{HASIL DAN PEMBAHASAN}

Tingkat keberhasilan anak pada observasi awal 20\%. Dan Hasil evaluasi pada siklus I dapat diketahui bahwa dalam meningkatkan kreativitas dalam membentuk objek melalui kardus geometri di kelompok B TK Kondowa Kecamatan Pasarwajo Kabupaten Buton pada siklus I, secara klasikal pada siklus I mencapai tingkat keberhasilan sekitar $66,7 \%$ dengan 10 anak, dimana 2 anak memperoleh bintang (****) atau Berkembang Sangat Baik dengan persentase $13,3 \%$ dan 8 anak memperoleh nilai bintang $(* * *)$ dengan persentase $53,3 \%$. Berdasarkan hasil evaluasi tersebut sebagian besar anak sudah dapat melaksanakan kegiatan dengan baik. Dan hasil perhitungan nilai secara klasikal pada siklus II yaitu 93,3\%, dengan 14 anak dimana5 anak memperoleh bintang (****) atau Berkembang Sangat Baik dengan persentase 33,3\% dan 9 anak memperoleh bintang (***) atau Berkembang Sesuai Harapan dengan persentase $60 \%$ dengan demikian anak telah mencapai indikator kinerja $85 \%$ anak memperoleh nilai Berkembang Sangat Baik (BSB) dan Berkembang Sesuai Harapan (BSH). Dengan demikian penelitian ini telah berhasil dilaksanakan, maka guru dan observer kelompok B sepakat untuk tidak melanjutkan pada tahap siklus selanjutnya, dengan kata lain tindakan penelitian ini dihentikan.

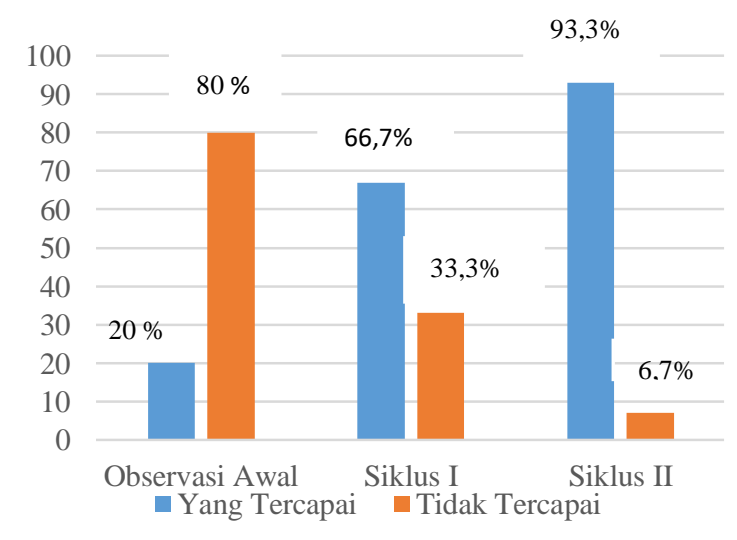

Gambar 1. Histogram Hasil Persentase Keberhasilan KlasikalObservasi Awal,Siklus I dan Siklus II

Berdasarkan histogram di atas menunjukkan bahwa kreativitas dalam membentuk objek melalui kardus geometri di
Kelompok B TK Kondowa Kecamatan Pasarwajo Kabupaten Buton dapat meningkat.

Berdasarkan permasalahan yang telah dirumuskan dalam penelitian ini, tujuan yang ingin dicapai dalam skripsi ini yaitu untuk meningkatkan kreativitas dalam membentuk objek melalui kardus geometri di Kelompok B TK Kondowa Kecamatan Pasarwajo Kabupaten Buton. Penelitian ini dilaksanakan dalam dua siklus, dimana setiap siklus terdiri dari tiga kali pertemuan sesuai dengan prosedur penelitian yang telah dirancang sebelumnya. Setiap pertemuan terdiri dari tiga tahap yaitu kegiatan awal, kegiatan inti dan kegiatan akhir.

Hasil analisis observasi mengajar guru sesuai dengan pedoman/lembar obsevasi sebanyak 14 aspek yang telah dicapai oleh guru. Pada siklus I yang dicapai guru yaitu 64,3\% atau 9 aspek yang tercapai, kemudian mengalami peningkatan pada siklus II sebesar 92,8\% atau 13 aspek dari 14 aspek pengamatan. Sedangkan aktivitas belajar anak didik pada siklus I yang dicapai anak yaitu $57,1 \%$ atau 8 aspek yang tercapai kemudian mengalami peningkatan pada siklus II sebesar $92,8 \%$ atau 13 aspek yang tercapai.

\section{KESIMPULAN DAN SARAN}

\section{Kesimpulan}

Berdasarkan analisis data hasil observasi aktivitas mengajar guru pada siklus I diperoleh persentase ketercapaian sebesar 64,3\%, aktivitas belajar anak didik pada siklus I diperoleh persentase ketercapaian sebesar $57,1 \%$ Pada siklus II, persentase ketercapaian aktivitas mengajar guru mengalami peningkatan sebesar $92,8 \%$, persentase belajar anak didik pada siklus II mengalami peningkatan sebesar 92,8\%

Berdasarkan hasil observasi yang telah dilakukan peneliti pada anak didik di kelompok B TK Kondowa Kecamatan Pasarwajo Kabupaten Buton pada observasi siklus I mencapai persentase sebesar $66,6 \%$. Pada siklus II meningkat dengan persentase 93,3\% ketuntasan secara klasikal.

Berdasarkan hasil penelitian dan pembahasan pada siklus I dan siklus II, maka dapat disimpulkan bahwa kreativitas dalam membentuk objekdi Kelompok B TK Kondowa Kecamatan Pasarwajo Kabupaten Buton dapat ditingkatkan dengan menggunakan kardus geometri. 


\section{Saran}

a. Bagi Guru, sebaiknya guru menggunakan kardus geometri sebagai salah satu cara untuk meningkatkan kreativitas anak dalam membentuk objek karena dari hasil penelitian terbukti bahwa melalui kardus geometri dapat meningkatkan kreativitas dalam membentuk objek.

b. Bagi Sekolah, memberikan dan menyediakan fasilitas yang mendukung dalam membentuk objek dengan menggunakan kardus geometri dapat mendukung upaya guru dalam menggunakan kardus geometri untuk meningkatkan kreativitas dalam membentuk objek.

c. Bagi Peneliti Selanjutnya mengenai peningkatan kreativitas anak dalam membentuk objekmelalui kardus geometri masih banyak kekuranganyakni tampilan kardus geometri diharapkan agar dibuat lebih menarik lagi. Oleh karena itu, menjadi motivasi bagi peneliti selanjutnya untuk melengkapi penelitian ini, yaitu variasi yang lebih menarik, sehingga dapat meningkatkan kreativitas anak.

\section{DAFTAR PUSTAKA}

Ana, Craft. 2004. Membangun Kreativitas Anak. Depok: Insani Press.

Anonim. 1999. Kamus Besar Bahasa Indonesia. Jakarta: Erlangga.

Anonim. 2001. Undang-Undang RI No 20 Tahun 2003 Tentang Sistem Penidikan Nasional. Jakarta: Depdiknas.

Arikunto, Suharsimi. 2014. Prosedur Penelitian Suatu Pendekatan Praktik. Jakarta : Rineka Cipta.

Depdiknas. 2004. Pedoman Penilaian di Taman Kanak-Kanak. Jakarta: Depdiknas.

Fadlillah, Muhammad. 2012. Desain Pembelajaran PAUD: Panduan untuk Pendidik, Mahasiswa, \& Pengelola Pendidikan Anak Usia Dini. Tinjauan Teoretik \& Praktik. Jogjakarta: Ar-Ruzz Media.

Negoro, ST. 2003. Ensiklopedia Matematika. Bogor: Ghalia Indonesia.

Rachmawati, Yeni dan Euis Kurniati. 2010. Strategi Pengembangan Kreativitas
Pada Anak Usia Taman Kanak-Kanak. Jakarta: Kencana.

Tombokan, Rontukahu. 1996. Pengajaran Matematika Bagi Anak Berkesulitan Belajar. Jakarta: Departemen Pendidikan dan Kebudayaan.

Utami, Munandar. 1992. Mengembangkan Bakat dan Kreativitas Anak Sekolah. Jakarta: PT. Gramedia Widiasarana Indonesia.

Yeni Rahmawati \& Euis Kurniati, 2005. Strategi Pengembangan Kreativitas Pendidikan Anak Usia Taman Kanak-Kanak. Jakarta: Rineka Cipta 